\title{
A RESEARCH SYNTHESIS OF TEXT MESSAGING AND DRIVING PERFORMANCE
}

\author{
Jeff K. Caird ${ }^{1}$, Kate Johnston ${ }^{1}$, Chelsea Willness ${ }^{2}$ \& Mark Asbridge $^{3}$ \\ ${ }^{1}$ University of Calgary, Calgary, Alberta, Canada \\ ${ }^{2}$ University of Saskatchewan, Saskatoon, Saskatchewan, Canada \\ ${ }^{3}$ Dalhousie University, Halifax, Nova Scotia, Canada \\ Email: jkcaird@ucalgary.ca
}

\begin{abstract}
Summary: To determine the effects of text messaging on driving performance, all available experimental studies that measured driving performance were identified through a variety of database searches and backtracking strategies, and analyzed using standard research synthesis methods. Fourteen studies with a total of 519 participants were coded and analyzed. Methodology, independent and dependent variables, and statistical analyses varied widely across studies, but conclusions were clear and convergent. Reaction time, crashes, longitudinal and lateral control, eye movements, hazard detection and subjective workload measures indicate significant decrements in driving performance while reading and typing text messages. The importance of the results for further policy development and methodological reporting is briefly introduced.
\end{abstract}

\section{INTRODUCTION}

To many, text messaging while driving is regarded as unsafe. Nevertheless, communicating with friends, family and co-workers may take precedence over attending to driving. In a national U.S. survey, 18 percent of all drivers and 49 percent of those 21 to 24 reported texting and driving (Tison, Chaudhary \& Cosgrove, 2011). Surveys of drivers report increasing rates of texting and driving-particularly among young and novice drivers (O’Brien, Goodwin \& Foss, 2010). Relatively speaking, the body of research on text messaging while driving has lagged somewhat behind the observed increased volume of texting in recent years. The purpose of this paper is to synthesize the available experimental evidence of the effects of text messaging on driving performance in order to highlight the societal importance of this issue.

A population-based study and a naturalistic study have linked texting while driving to crashes. Wilson and Stimpson (2010) conducted a multivariate regression analysis of the FARS database (Fatality Accident Reporting System, U.S.) and found that the percent of total fatalities from distracted driving increased from 10.9 percent in 1999 to 15.8 percent in 2008. The increase in fatalities from 2002 to 2007 is likely the result of year over year increases in text messaging while driving: the study concluded that an estimated 16,141 additional fatalities resulted from texting while driving for that time period. The media and researchers frequently cite the naturalistic study by Olson and others where a 23 times greater odds of a crash was found for truck drivers who were texting and driving (Olson, Hanowski, Hickman \& Bocanegra, 2009). Specifically, texting was found to increase the odds of being involved in crash, near miss or incident for truck drivers (OR = 23.24, 95\% CI = 9.69-55.73).

The first paper to address the experimental effects of text messaging on driving performance in passenger vehicles appeared as part of larger set of studies on cell phone use in Sweden (Kircher 
et al., 2004); although an earlier study by Tijerina, Kiger, Rockwell and Tarnow (1995) evaluated the effects of reading text messages of different lengths on the driving performance of truck drivers. The first study to focus entirely on text messaging and driving performance was completed by Hosking, Young and Regan (2006) in Melbourne, Australia. Among these and other driving performance studies regarding the effects of text messaging, study methodology varies widely with a diverse set of independent and dependent variables being examined. Given this diversity in study findings, coupled with the emergence of texting as a common practice of everyday life, a systematic review and synthesis of the evidence on the impact of texting on driving performance is warranted, with the aim of improving road safety.

\section{METHOD}

The purpose of a research synthesis is to "integrate empirical research for the purpose of creating generalizations” (Cooper, Hedges \& Valentine, 2009, p. 6). The use of meta-analysis, which is a set of statistical procedures that combines effect sizes, was not performed here because of issues in the identified studies including missing post hoc comparisons, lack of measurement definitions and insufficient methods descriptions. The steps of a research synthesis, which follow, include indentifying studies, data extraction, coding and thematic analysis (Higgins \& Green, 2008).

Data Sources, Search Strategy and Study Selection. Using key word variants of driving and text messaging, a number of databases (Google Scholar, PsychINFO, PubMed, SafetyLit, etc.), journals (Accident Analysis and Prevention, Human Factors, Traffic Injury Prevention, etc.) proceedings (Driving Assessment, Human Factors and Ergonomics Society, Transportation Research Board, etc.) and government web sites (NHTSA, SWOV, VTI, etc.) were searched for text messaging and driving studies without restriction of date, language, year of publication and source (e.g., article, technical report, proceedings paper, etc.). Backtracking from reference sections was also used to identify additional studies.

Data Extraction and Coding. Complete publications were further analyzed to determine whether a study met the established criteria for inclusion. These criteria were first, the study had to measure driving performance, which was defined as controlling a vehicle, simulation or proxy task. Second, study participants had to be driving and reading or writing text messages compared to a baseline control. Texting was defined as reading and/or typing messages as well as associated device manipulation and interface interaction. Two coders extracted measures from all studies and categorization discrepancies were reconciled by discussion.

\section{RESULTS}

Search Results. A total of 1,438 abstracts were identified through database search and backtracking strategies. Of these, 1,386 were excluded because they did not focus on driving and text messaging. The remaining 52 complete publications were obtained for further analysis. Careful review resulted in an additional 38 papers being excluded because the focus of study used non-experimental methods including surveys, questionnaires, observations and databases. Two studies did not report sufficient statistical information to be used. Fourteen studies met the inclusion criteria. 
Baseline Characteristics. Study characteristics and independent variables are listed in Table 1. A number of studies had conditions in addition to texting that were not the focus of this synthesis. For example, the effects of eating as a distraction (Alosco et al., 2012) and text to speech as a potential technological alternative to texting (Owens, McLaughlin \& Sudweeks, 2010) were not coded. Only texting conditions were coded.

Table 1. List of studies, characteristics and independent variables

\begin{tabular}{|c|c|c|c|c|c|}
\hline Study & $\begin{array}{l}\text { Pub. } \\
\text { Year }\end{array}$ & Exp. Setting & $\mathbf{N}$ & $\begin{array}{l}\text { Participants Sampled } \\
\text { Ages and Gender }\end{array}$ & $\begin{array}{l}\text { Independent } \\
\text { Variables }\end{array}$ \\
\hline 1. Alosca et al. & 2012 & Simulator & $\begin{array}{c}143 \\
*\end{array}$ & $\begin{array}{l}\text { Texting: } \mathrm{N}=45,20.2 \text { Yr., } \\
\text { Control: } \mathrm{N}=98,19.9 \text { Yr. } \\
\text { T: } 76.4 \% \text { F; C: } 56.4 \% \text { F }\end{array}$ & Text v. Control \\
\hline 2. Bruge \& Chaparro & 2012 & Simulator & 20 & $\begin{array}{l}\text { Ages: } 18 \text { to } 55 \text {, } \\
10 \mathrm{M}, 10 \mathrm{~F}\end{array}$ & $\begin{array}{l}\text { Alpha., Copy Text } \\
\text { v. Base }\end{array}$ \\
\hline 3. Crandall \& Chaparro & 2012 & Simulator & 23 & $\begin{array}{l}\text { Ages: } 18 \text { to } 40 \\
14 \mathrm{M}, 9 \mathrm{~F}\end{array}$ & $\begin{array}{l}\text { TS, KB v. } \\
\text { Base }\end{array}$ \\
\hline 4. Crisler et al. & 2008 & Simulator & 14 & $\begin{array}{l}\text { Ages: } 18 \text { to } 22 \\
7 \mathrm{M}, 7 \mathrm{~F}\end{array}$ & $\begin{array}{l}\text { Text (word game, } \\
\text { conv.) v. Base }\end{array}$ \\
\hline 5. Drews et al. & 2009 & Simulator & 40 & $\begin{array}{l}\text { Ages: } 19 \text { to } 23 \\
20 \mathrm{M}, 20 \mathrm{~F} \text { (20 dyads) }\end{array}$ & $\begin{array}{l}\text { Receive and Send } \\
\text { v. Base }\end{array}$ \\
\hline 6. Hosking et al. & 2009 & Simulator & 20 & $\begin{array}{l}\text { Ages: } 18 \text { to } 21 \\
12 \mathrm{M}, 8 \mathrm{~F}\end{array}$ & Send, Rec. v. Base \\
\hline 7. Kircher et al. & 2004 & Simulator & 10 & $\begin{array}{l}\text { Mean Age }=28.7 \\
7 \mathrm{M}, 3 \mathrm{~F}\end{array}$ & $\begin{array}{l}\text { Read Text Aloud v. } \\
\text { Base }\end{array}$ \\
\hline 8. Leung et al. & 2012 & Simulator & 12 & $\begin{array}{l}\text { Ages: } 23.5 \text { to } 30.8 \\
2 \mathrm{M}, 10 \mathrm{~F}\end{array}$ & Text v. Base \\
\hline 9. Libby \& Chaparro & 2009 & Simulator & 34 & $\begin{array}{l}\text { Ages: } 18 \text { to } 58 \\
5 \mathrm{M}, 29 \mathrm{~F}\end{array}$ & Text v. CP and VR \\
\hline 10. Owens et al. & 2011 & $\begin{array}{l}\text { Closed Test } \\
\text { Track }\end{array}$ & 20 & $\begin{array}{l}\text { Ages: Y } 11,19 \text { to } 34 \\
\text { Old } 9,39 \text { to } 51 ; 11 \mathrm{M}, 9 \mathrm{~F}\end{array}$ & $\begin{array}{l}\text { Text v. Base; } \\
\text { Y/O }\end{array}$ \\
\hline 11. Ranney et al. & 2011 & Simulator & 100 & $\begin{array}{l}\text { Ages: } 25 \text { to } 64 \\
50 \mathrm{M}, 50 \mathrm{~F}\end{array}$ & $\begin{array}{l}\text { Text v. Other } \\
\text { Secondary Tasks }\end{array}$ \\
\hline 12. Reed \& Robbins & 2008 & Simulator & 17 & $\begin{array}{l}\text { Ages: } 17 \text { to } 25 \\
8 \mathrm{M}, 9 \mathrm{~F}\end{array}$ & Read, Write v. Base \\
\hline 13. Rudin-Brown et al. & 2012 & Simulator & 24 & $\begin{array}{l}\text { Ages: } 25 \text { to } 50 \\
12 \mathrm{M}, 12 \mathrm{~F}\end{array}$ & $\begin{array}{l}\text { Read, Read and } \\
\text { Write v. Base }\end{array}$ \\
\hline 14. Yager et al. & 2012 & $\begin{array}{l}\text { Closed Test } \\
\text { Track }\end{array}$ & 42 & $\begin{array}{l}\text { Ages: } 16 \& 17,2,18 \text { to } 35 \text {, } \\
32 ; 35+, 8,7 \mathrm{M}, 25 \mathrm{~F}\end{array}$ & Read, Send v. Base \\
\hline Totals: 14 & $\begin{array}{l}2004- \\
2012\end{array}$ & $\begin{array}{l}\text { Sim. }=13 \\
\text { Track }=2\end{array}$ & 519 & $\begin{array}{l}\text { Age Range: } 16 \text { to } 72 \\
\text { Men 229; Women } 290\end{array}$ & $\begin{array}{l}\text { Send: } 12 \\
\text { Receive: } 5\end{array}$ \\
\hline
\end{tabular}

Notes. Pub. is publication, Exp. is experimental, $N$ is number of participants, Send is typing a text message, Rec. is reading a text message, $M$ is male, $F$ is female, Ind. is independent, Var. is variable, Base is baseline, $\mathrm{Sim}$. is simulator, Veh. is vehicle, $Y$ is young, $O$ is old, $T$ is texting, Conv. is converse, $C P$ is cell phone, TS is touch screen, $K B$ is keyboard, $V R$ is verbal report, Alpha is alphabetize, Str. is straight. *Between-subjects groups of texting and control. All other studies used within-subjects experimental designs.

The number of studies reported in the literature from 2004 to present has increased and more so in the past several years (3 in 2011; 6 in 2012). Most studies were performed in simulators of varying types ( $N=14$ ) and in the U.S. $(N=9)$ in addition to Australia (3), U.K. (1), and Sweden (1). A total of 519 participants from a number of sample groups were represented in the set of studies. Most studies compared sending and/or receiving texting with a control group or a 
baseline performance without texting, but one study was included that made comparisons among secondary tasks without reference to baseline driving performance (e.g., Ranney, Baldwin, Parmer, Martin \& Mazzae, 2011). For this study, a conservative coding strategy was used that coded a measure only if the texting task was significantly worse than other secondary tasks.

Dependent Variable Coding. Dependent variable categories included reaction time (RT), crashes, lateral and longitudinal vehicle control, eye movements, detection and subjective workload (see Caird \& Horrey, 2011 for definitions). Within each dependent variable category, variants of each measure were included across studies. For the purposes of showing the overall pattern of results, these variants were collapsed into the categories shown in Table 2. Individual studies could contribute more than one measure per category to significant $(*)$ or non-significant (ns) counts.

Table 2. Dependent variable categories for receive and send text messages versus baseline

\begin{tabular}{|c|c|c|c|}
\hline $\begin{array}{l}\text { Dependent Variable } \\
\text { Category }\end{array}$ & $\begin{array}{l}\text { Number of } \\
\text { Studies }\end{array}$ & $\begin{array}{l}\text { Receive (Read) } \\
\text { v. Baseline }\end{array}$ & $\begin{array}{l}\text { Send (Read, Type) } \\
\text { v. Baseline }\end{array}$ \\
\hline Reaction Time (RT) & 8 & $3 *+$ & $8 *+, 4 \mathrm{~ns}$ \\
\hline Crashes & 2 & - & $2^{*+}$ \\
\hline Lateral Control & 13 & $4 *+, 4 \mathrm{~ns}$ & $17 *+, 1 \mathrm{~ns}$ \\
\hline $\begin{array}{l}\text { Longitudinal Control } \\
\text { Speed } \\
\text { Speed Variability } \\
\text { Headway (t, d) } \\
\text { Minimum Headway }\end{array}$ & 7 & - & $\begin{array}{l}4 *_{-}, 1 *_{+} \\
3 *_{+} \\
6 *_{+}, 1 \mathrm{~ns} \\
1 *_{-}\end{array}$ \\
\hline Eye Movements & 4 & $2 *+, 2 \mathrm{~ns}$ & $7 *+$ \\
\hline $\begin{array}{l}\text { Detection } \\
\text { Missed Hazards } \\
\text { Missed Secondary Tasks } \\
\text { Proportion Correct }\end{array}$ & 5 & $1 *+$ & $\begin{array}{l}4 *_{+} \\
1 *_{+} \\
1 *_{-}\end{array}$ \\
\hline Subjective Workload & 3 & $1 *+$ & $2 *+, 1 \mathrm{~ns}$ \\
\hline
\end{tabular}

Notes. * indicates a significant difference from baseline, control or other tasks, - indicates a measure that is less than the baseline value, + represents more of a measure than the baseline, ns is not significant.

Thematic Analysis. For reaction time (see Table 2 above), participants had slower responses to events in receive and send conditions. However, not all events produced slower responses than baseline in the send condition. Across studies, typing a text while steering affected the lateral control of the vehicle within a lane. Drivers tended to travel slower while typing a text and were more variable while maintaining their speed. Similarly, longer headways were adopted while reading and typing texts. Adopting lower speeds and longer headways while typing texts may or may not compensate for attention being directed away from the roadway. Across studies, participants made more glances away from the roadway while reading and typing texts. Across studies, more hazards and secondary tasks were missed while sending texts. 


\section{DISCUSSION}

This research synthesis confirms that text messaging while driving adversely affects numerous measures of driving performance (see Table 2). Overall, drivers in experimental studies showed slower reaction times, a higher number of crashes, greater variability in lateral and longitudinal control, prolonged glances away from the road, more missed hazards, and higher workload while sending text messages and driving. Fewer studies had experimental conditions where reading a text message was separate from writing and/or reading a text and the pattern of results while reading indicated less of an impact on lateral vehicle control and glances away from the road.

This synthesis of driving performance research is convergent with the naturalistic, self-report and epidemiological research on texting and driving (Olson, Hanowski, Hickman \& Sudweeks, 2009; Tison, Chaudhary \& Cosgrove, 2011; Wilson \& Stimpson, 2010). The accumulated evidence across research approaches for the safety costs of text messaging while driving is uniformly negative, unequivocal and convergent. Sending and receiving text messages compromises the safety of the driver, passengers and other motorists and will cause an increasing number of deaths and injuries in the years to come especially if the prevalence of texting continues to escalate.

To prevent this potential future, sending and receiving text messages should be targeted by legislation, enforcement, social norms, parent modeling, peer pressure, blocking technologies, training and education. Currently, 39 states, the District of Columbia, Guam and the Virgin Islands have banned texting and driving and an additional five states limit texting for novice drivers (GHSA, 2012). However, the extent that legislation has or will reduce the frequency of texting and driving behavior may be less than expected (Goodwin et al., 2012). Clearly a multimethod prevention approach will be required.

Methodological and statistical details matter to research synthesis and meta-analysis (Caird, Willness, Steel \& Scialfa, 2008). Studies included in this synthesis frequently lacked sufficient methodological and statistical detail. Green (2012) provides a detailed analysis of similar methodological and definitional problems from papers at the first Automotive UI conference. In our synthesis, "cell phone" is an insufficient experimental description of the means to send a text message. Over time, cell or smart phones change rapidly and various software and hardware interfaces require complete specification (e.g., t-9, swipe, QWERTY, hard keys, touchscreens, etc.). Interaction constraints affect typing errors and task completion times and thus may also affect driving performance.

\section{ACKNOWLEDGMENTS}

The AUTO21 Network of Centres of Excellence (NCE) supported this research.

\section{REFERENCES}

Studies preceded by an * were analyzed in this research synthesis.

*Alosco, M.L., Spitznagel, M.B., Fischer, K.H., Miller, L.A., Venugopal, V., Hughes, J., \& Gusnstad, J. (2012). Both texting and eating are associated with impaired simulator driving performance. Traffic Injury Prevention, 13(5), 468-475. 
*Burge, R., \& Chaparro, A. (2012). The effects of text messaging on hazard perception. Proceedings of the Human Factors and Ergonomics $56^{\text {th }}$ Annual Meeting (pp. 715-719). Santa Monica, CA: HFES.

Caird, J.K., \& Horrey, W. (2011). Twelve practical and useful questions about driving simulation. In Fisher, D.L., Rizzo, M., Caird, J.K., \& Lee, J.D. (Eds). (2011). Handbook of Driving Simulation for Engineering, Medicine, and Psychology (pp. 5-1 to 5-18). Boca Raton, FL: CRC Press.

Caird, J.K., Willness, C., Steel, P., \& Scialfa, C. (2008). A meta-analysis of cell phone use on driver performance. Accident Analysis and Prevention, 40, 1282-1293.

Cooper, H., Hedges, L.V., \& Valentine, J.C. (Eds.) (2009). The handbook of research synthesis and meta-analysis ( $2^{\text {nd }} E d$.). New York: Russell Sage Foundation.

*Crandall, J.M., \& Chaparro, A. (2012). Driver distraction: Effects of text entry methods on driving performance. Proceedings of the Human Factors and Ergonomics $56^{\text {th }}$ Annual Meeting (pp. 1693-1697). Santa Monica, CA: HFES.

*Crisler, M.C., Brooks, J.O., Ogle, J.H., Guirl, C.D., Alluri, P., \& Dixon, K.K. (2008). Effect of wireless communication and entertainment devices on simulated driving peformance. Transportation Research Record 2069, 48-54.

*Drews, F.A., Yazdani, H., Godfrey, C.N., Cooper, J.M., \& Strayer, D.L. (2009). Text messaging during simulated driving. Human Factors, 51(5), 762-770.

Goodwin, A.H., O’Brien, N.P., \& Foss, F.D. (2012). Effect of North Carolina’s restriction on teenage driver cell phone use two years after implementation. Accident Analysis and Prevention, 48, 363-367.

Govenors Highway Safety Association (2012). Cell phone and texting laws. [Accessed Nov. 11, 2012] http://www.ghsa.org/html/stateinfo/laws/cellphone_laws.html

Green, P. (2012). Using standards to improve the replicability and applicability of driver interface research. Automotive UI, Portsmouth, NH.

Higgens, J.P.T., \& Green, S. (2008). Cochrane handbook for systematic reviews of interventions. Hoboken, NJ: Wiley-Blackwell.

Hosking, S., Young, K., \& Regan, M. (2006). The effects of text messaging on young novice driver performance (Rep. No. 246). Melbourne, Australia: Monash University Accident Research Centre.

*Hosking, S., Young, K., \& Regan, M. (2009). The effects of text messaging on young drivers. Human Factors, 51(4), 582-592.

*Kircher, A., Vogel, K., Tornros, J., Bolling, A., Nilsson, L., Patten, et al. (2004). Mobile telephone simulator study (Rep. No. 969A). Linköping, Sweden; Swedish National Road and Transport Research Institute.

*Leung, S., Croft, R.D., Jackson, M.L., Howard, M.E., \& McKenzie, R.J. (2012). A comparison of the effect of mobile phone use and alcohol consumption on driving simulation performance. Traffic Injury Prevention, 13, 566-574. 
*Libby, D., \& Chaparro, A. (2009). Text messaging versus talking on a cell phone: A comparison of their effects on driving performance. Proceedings of the Human Factors and Ergonomics 53 ${ }^{\text {th }}$ Annual Meeting (pp. 1353-1357). Santa Monica, CA: HFES.

O’Brien, N.P., Goodwin, A.H., \& Foss, R.D. (2010). Talking and texting among teenage drivers: A glass half empty or half full. Traffic Injury Prevention, 11, 549-554.

Olson, R., Hanowski, R., Hickman, J., \& Bocanegra, J. (2009). Driver distraction in commercial vehicle operations (Rep. No. FMCSA-RRR-09-042). Washington, DC: Federal Motor Carrier Safety Administration.

*Owens, J.M., McLaughlin, S.B., \& Sudweeks, J. (2011). Driver performance while text messaging using handheld and in-vehicle systems. Accident Analysis and Prevention, 43, 939-947.

*Ranney, T.A., Baldwin, S., Parmer, E., Martin, J., \& Mazzae, E.N. (2011). Distraction effects of manual number and text entry while driving (Rep. No. DOT HS 811 510). Washington, D.C.: National Highway Traffic Safety Administration.

*Reed, N., \& Robbins, R. (2008). The effect of text messaging on driver behaviour (Rep. PPR 387). Transport Research Laboratory.

*Rudin-Brown, C.M., Young, K., Patten,C., Lenne, M.G., \& Ceci, R. (2012). Driver distraction in an unusual environment: Effects of text messaging in tunnels. Accident Analysis and Prevention, 50, 122-129.

Tijerina, L., Kiger, S.M., Rockwell, T.H., \& Tarnow, C. (1995). Workload assessment of in-cab text message and cellular phone use by heavy vehicle drivers on the road. Proceedings of the Human Factors and Ergonomics $39^{\text {th }}$ Annual Meeting (pp. 1117-1121). Santa Monica, CA: HFES.

Tison, J., Chaudhary, N., \& Cosgrove, L. (2011). National phone survey on distracted driving attitudes and behaviors (Rep. No. DOT HS 811 555). Washington, DC: National Traffic Safety Administration.

Wilson, F.A., \& Stimpson, J.P. (2010). Trends in fatalities from distracted driving in the United States, 1999 to 2008. American Journal of Public Health, 100(11), 2213-2219.

*Yager, C., Cooper, J.M., \& Chrysler, S.T. (2012). The effects of reading and writing text-based messages while driving. Proceedings of the Human Factors and Ergonomics $56^{\text {th }}$ Annual Meeting (pp. 2196-2200). Santa Monica, CA: HFES. 